\title{
PANTOTHENIC ACID DEFICIENCY INDUCED IN HUMAN SUBJECTS ${ }^{1}$
}

\author{
By WILLIAM B. BEAN, ROBERT E. HODGES, AND KATE DAUM WITH THE ADVICE AND \\ TECHNICAL ASSISTANCE OF JAMES T. BRADBURY, RUTH GUNNING, JOSEFINE \\ MANRESA, WILLIAM MURRAY, PATRICIA OLIVER, JOSEPH I. ROUTH, \\ HAROLD P. SCHEDL, MARY TOWNSEND, AND I. CHU TUNG
}

\author{
(From the Metabolism Unit of the Department of Medicine and the University Hospitals of \\ The State University of Iowa, Iowa City, Ia.)
}

(Submitted for publication January 13, 1955; accepted March 23, 1955)

Bean and Hodges (1) gave a preliminary report of four young men in whom clinical disorders and metabolic faults were induced by a "diet" devoid of pantothenic acid, with omega-methylpantothenic acid, a vitamin antagonist (Figure 1). It is proposed here to describe details of the experiments, results, and some interpretations. The background for using molecular antagonists $(2,3)$ in human nutrition had been explored previously using antagonists to nicotinic acid (4).

Among the accepted B-complex vitamins, pantothenic acid has been most puzzling in human nutrition. Its discovery by Williams, Lyman, Goodyear, Truesdail, and Holaday (5) and its presence in coenzyme A (6) suggested metabolic functions in man. Its employment in treating undernourished persons yielded no clue. Data from experimental animals revealed that the principal manifestations of its deficiency are those of adrenal cortical failure, accompanied by low plasma cholesterol, gastrointestinal symptoms and lesions, impaired antibody production, neurological lesions and alterations of the epidermis $(7-11)$. The function of pantothenic acid in animals has been clarified by Drell, Dunn and their co-workers (1215) who synthesized omega-methylpantothenic acid, demonstrated that it antagonized pantothenic acid, determined its toxicity in animals and showed that its deleterious effects could be reversed or prevented by pantothenic acid. Some of these observations were verified and extended by Shils (16).

\section{PROCEDURES}

Early in 1950 we tried to induce pantothenic acid deficiency in a healthy young man. With the principle of metabolic antagonists well established, with pantothenic

\footnotetext{
1 Supported by The Medical Department Trust Fund and grants from the Eli Lilly Company, The Nutrition Foundation and The National Vitamin Foundation.
}

acid available for parenteral use, with several adrenal steroids and ACTH on hand, and with the clear understanding by the subject that he might suffer bad effects (17), we proceeded with an experiment of probable hazard. Several of us took small and then larger amounts of pantoyltaurine (18) for taste, irritating effects and any obvious sign or symptom. It produced no effect. After six months the first subject, eating a good diet, was taking 4 grams of pantoyltaurine a day without any observable effect on signs or symptoms. Since the hospital diet had more pantothenic acid than was reported in standard tables, a mixture of synthetic and purified preparations, supplemented with minerals and the known vitamins, except for pantothenic acid, was

\section{CHEMICAL FORMULAE}

I.Pontothenic Acid<smiles>CC(C)(CO)C(O)C(=O)NCC(=O)O</smiles>

\section{2.omego-Methylpontothenic Acid}

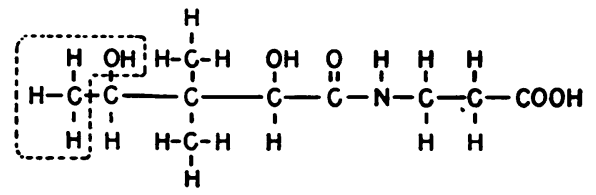

\section{Pontoyltourine}

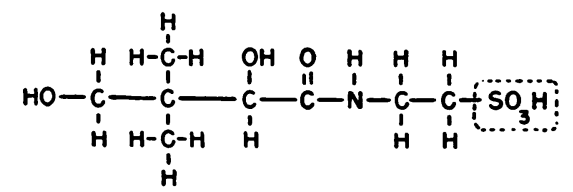

4. $\beta(\gamma-L-$ Glutomyl)-Aminopropionitrile

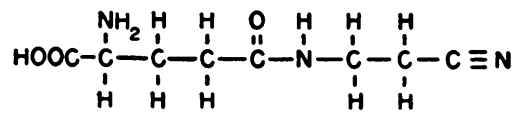

Fig. 1. Structural Formula of Pantothenic Acm and Related Compounds 
TABLE I

\begin{tabular}{|c|c|c|c|c|c|}
\hline \multicolumn{2}{|c|}{ Composition of formula } & \multicolumn{2}{|l|}{ Vitamin supplement } & \multicolumn{2}{|l|}{ Composition of salt mixture } \\
\hline $\begin{array}{l}\text { Granulated sugar } \\
\text { Cornstarch } \\
\text { Water } \\
\text { Vitamin-free casein* } \\
\text { Corn oil } \\
\text { Cystine } \\
\text { Vitamin A } \\
\text { Vitamin D }^{\text {NitamCO }} \\
\text { NaHC }_{3} \\
\text { Calories }\end{array}$ & $\begin{array}{l}290 \mathrm{gm} . \\
75 \mathrm{gm} . \\
750 \mathrm{ml} . \\
125 \mathrm{gm} . \\
90 \mathrm{gm} . \\
750 \mathrm{mg} . \\
5330 \text { U.S.P. units } \\
1070 \text { U.S.P. units } \\
10 \mathrm{gm} . \\
3000\end{array}$ & $\begin{array}{l}\text { Thiamine hydrochloride } \\
\text { Riboflavin } \\
\text { Pyridoxine } \\
\text { Ascorbic acid } \\
\text { Niacin }\end{array}$ & $\begin{array}{r}m g . \\
1.2 \\
1.8 \\
2.0 \\
50.0 \\
12.0\end{array}$ & $\begin{array}{l}\text { Calcium biphosphate } \\
\text { Calcium lactate } \\
\text { Ferric citrate } \\
\text { Magnesium sulfate } \\
\text { Dibasic potassium phosphate } \\
\text { Sodium biphosphate } \\
\text { Sodium chloride }\end{array}$ & \begin{aligned} \multicolumn{1}{c}{$m g} \\
67.9 \\
163.5 \\
14.9 \\
68.5 \\
119.9 \\
43.6 \\
21.8\end{aligned}$. \\
\hline
\end{tabular}

Subjects

The three subjects $\dagger$ had the following characteristics:

M. C. was a 29-year old man who had always had excellent health. The past history was negative except for a fracture of the nose eight years previously and a Neisserian infection ten years previously. The height was 5 feet 9 inches and the weight was 137 pounds. He was normal except for a deviated septum and a few carious teeth. The arterial blood pressure was $110 / 60$.

L. N. was a 32-year old man who had always had excellent health. His past history revealed pneumonia in childhood and dysentery in 1941 while in military service. His height was 5 feet 8 inches and his weight was 188 pounds. He was slightly fat and had some carious teeth. His arterial blood pressure was $130 / 80$.

E. D. was a 27-year old man who had had excellent health. His past history revealed a few episodes of pleuritic pain in the left side of the chest a year previously and an attack of phlebitis in the leg many years ago. The physical examination revealed a normal man. X-ray of the chest revealed no lesion. His height was 5 feet 8 inches and his weight 138 pounds. His arterial blood pressure was $130 / 78$.

* Contains $20 \mathrm{mcg}$. Vitamin $\mathrm{B}_{12}$ by assay.

$\dagger$ We were enabled to do the study with prisoners as volunteers through the thoughtful cooperation of Mr. Roy Purcell, warden of the Iowa State Reformatory at Anamosa, and with the authorization of the State Board of Control, Mr. Henry W. Burma, Chairman.

used. The formula (Table I) had to be given by stomach tube. Without any added antagonist it caused lowering of plasma cholesterol and some impairment of the eosinopenic response to ACTH. Clinical signs of deficiency did not appear.

To this pantothenic acid free diet we added the antagonist, pantoyltaurine (Figure 1). After twenty months elapsed with several periods of return to a normal diet, no obvious effect was produced by pantoyltaurine in quantities several hundred times greater than the average daily intake of pantothenic acid. The pantothenic acid free diet alone for four weeks or with pantoyltaurine for eight weeks led to no symptom and little metabolic change. We concluded that pantoyltaurine was not an antagonist or might even act as a vitamin. It was absorbed and excreted in the urine which inhibited growth of the test organism while pantoyltaurine was being given. Since no sign was produced, and no significant change occurred in any of the tests we concluded that the diet was adequate, and the antagonist inert in the dose used.

The next step was made possible when omega-methylpantothenic acid (Figure 1) became available (13-15). After we had tried it for immediate acute toxic or irritating effects we gave it to three volunteers. In the original subject it produced biochemical lesions, symptoms, and signs. The formula, vitamins and salt mixture were given in three equal parts three times a day by stomach tube (Table I). The subjects adjusted well to this method of getting nourishment. Water and black coffee were allowed as desired. The subjects were examined daily. They were not confined to bed but were under surveillance by a nurse or attendant at all times. The biochemical tests were done according to the plan seen in Figure 2 and Table II.

TABLE II

Schedule of tests and methods

\begin{tabular}{l}
\hline \hline Daily \\
Acetylation of para-aminobenzoic acid (19) \\
Urinary 17-ketosteroids (20) \\
Urinary creatinine; 24 -hour urine volume \\
Body weight, basal and standing blood pressure and \\
pulse \\
Twice a week \\
Plasma cholesterol (21) \\
Plasma cholesterol esters (21) \\
Eosinophile response to ACTH $(22,23)$ \\
Once a week \\
Gastric analysis \\
Insulin sensitivity test $(24-29)$ \\
Glucose tolerance test \\
Water diuresis test $(30)$ \\
Blood studies \\
Every two weeks \\
Plasma protein tests $(31,32)$ \\
Bromsulphalein test \\
Color photographs \\
Irregular \\
Ca, P, N, balances \\
Excretion of thiamine, niacin and ascorbic acid (33-36)
\end{tabular}




\begin{tabular}{|c|c|c|c|c|c|c|c|}
\hline \multicolumn{3}{|c|}{ CONDITIONS } & $\mathbf{I}$ & $\mathbf{I}$ & mo & $\pi 0$ & IIC \\
\hline \multicolumn{3}{|l|}{ DURATION } & 12 Doys & 25 Doys & 6 Days & 10 Doys & 14 Doys \\
\hline \multicolumn{3}{|l|}{ DIET } & \multicolumn{3}{|c|}{ Special dief by stomoch tube } & $\begin{array}{c}\text { Well bolonced } \\
\text { normal diet }\end{array}$ & $\begin{array}{l}\text { Special diet by } \\
\text { stomach tube }\end{array}$ \\
\hline \multirow{3}{*}{ VITAMINS } & \multicolumn{2}{|c|}{$\begin{array}{l}\text { Panfothenic } \\
\text { Acid }\end{array}$} & $30 \mathrm{mg} / \mathrm{d}$ & None & $4000 \mathrm{mg} / \mathrm{d}$ & 2000 & $\mathrm{mg} / \mathrm{d}$ \\
\hline & \multicolumn{2}{|c|}{$8-12$} & $20 \mathrm{mcg}$ & $20 \mathrm{mcg}$ & $20 \mathrm{mcg}$ & $\begin{array}{l}1000 \text { mcg } \\
\text { first } 2 \text { days }\end{array}$ & $20 \mathrm{mcg}$ \\
\hline & \multicolumn{2}{|c|}{ Dthers } & As in Toble I & As in Table 1 & $\begin{array}{c}\text { As in } \\
\text { Table I }\end{array}$ & \multicolumn{2}{|c|}{ Twice quantity in Table I } \\
\hline \multicolumn{3}{|c|}{$\begin{array}{l}\text { ANTAGONIST } \\
\text { omego-Methylpon- } \\
\text { tothenic Acid }\end{array}$} & None & \multicolumn{2}{|c|}{$500 \mathrm{mg} / \mathrm{d}$} & None & None \\
\hline \multicolumn{2}{|c|}{ CORTISONE } & $\begin{array}{l}\text { E.D. } \\
M . C \\
L . N .\end{array}$ & $\begin{array}{l}\text { None } \\
\text { None } \\
\text { None }\end{array}$ & $\begin{array}{l}\text { None } \\
\text { None } \\
\text { None }\end{array}$ & $\begin{array}{c}+ \\
\text { None } \\
\text { None }\end{array}$ & $\begin{array}{l}t+ \\
t+t \\
t+t\end{array}$ & $\begin{array}{l}\text { None } \\
\text { None } \\
\text { None }\end{array}$ \\
\hline & & + & Subjects MC,LN & $\begin{array}{l}\text { culor injection o } \\
\text { mg Cortisone or } \\
5 " \\
5: \\
\vdots\end{array}$ & 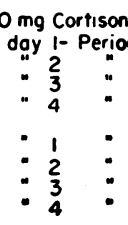 & $\begin{array}{l}\text { on doy 2, period } \\
\text { II b } \\
: \\
: \\
:\end{array}$ & III 0 \\
\hline
\end{tabular}

Fig. 2. The Pattern of Test Periods, Diet, Antagonists, Vitamins and Other THERAPY

The test ran from 23 March to 28 May, 1954.

Our original plan was to have three major experimental periods: I the control, II the deficiency, III the recovery, and, if time permitted, IV a repetition of the deficiency period. In actual fact the periods were arranged as follows: I, the control period, lasted for 12 days. Period II was the deficiency period. The only change was that the subjects got 0.5 grams of omegamethylpantothenic acid instead of pantothenic acid in the formula. This period continued for 25 days, by which time full-fledged manifestations of deficiency were apparent. Period III was divided into sections: III-a, 6 days, III-b, 10 days, and III-c, 14 days. The third period was to have been identical with the second except for 4 grams of pantothenic acid added to the diet every day. Early in this planned recovery period, though some improvement occurred, the well-being of the subjects was deteriorating. It was thought dangerous to continue. We gave cortisone as indicated in Figure 2 and a general diet during this 10 -day period; the antagonist was omitted. Period III-c lasted 14 days. The synthetic diet was resumed, and pantothenic acid was given in the amount of two grams daily. No further antagonist was given. The men were observed at intervals for a few months after the experiment. They showed no signs of persistent disorder except subject E. D. He had slight edema in the leg in which he had had phlebitis a number of years before. There was no recurrence of neurological sign or symptom.

\section{Clinical}

\section{RESULTS}

Some of the pitfalls in nutritional experiments in man have been noted (37). In the subjects, general appearance, skin, and mucous membranes did not change. During Period II the subjects, hitherto cheerful, became quarrelsome, sullen, and petulant. At times they spent most of the day in bed. Somnolence was particularly evident in L. N. and E. D. From the 12th to 16th days of Period II each subject independently complained of numbness and tingling of the hands and feet. At first this was transient and occurred only during inactivity. Later paresthesias were a constant source of annoyance. The men frequently stamped their feet and shook or wrung their hands in an effort to restore normal sensation. E. D. had an especially disagreeable burning sensation of his feet. M. C. developed a steppage gait with weak dorsiflexion of the feet ; the third complained of constant numbness of the hands. All subjects had hyperactive deep tendon reflexes, weakness of the extensor muscles and interossei of the hands, and inability to walk on tip-toe. Sensory perception remained intact for pain, thermal, vibratory and two-point sensation. Position sense was slightly impaired in one man. Plantar reflexes remained normal. The paresthesias cleared up completely in Period III-a but the motor changes did not. The motor changes cleared slowly in Period III-b and III-c. 


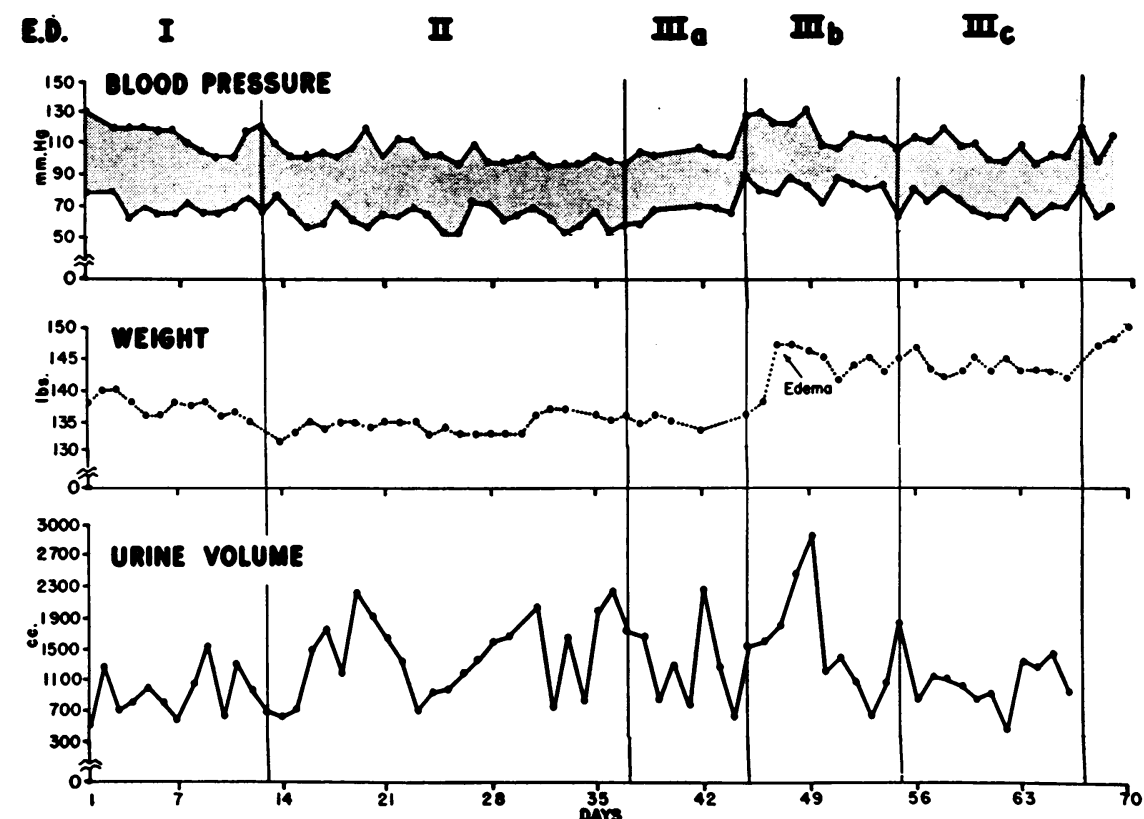

Fig. 3. Representative Chart of Blood Pressure, Weight and Urine Volume

Note the slight fall in resting blood pressure during Period II and the rise which coincided with the occurrence of edema. The edema persisted one to three weeks after cortisone was discontinued.

Gastrointestinal changes are the subject of a The three subjects showed less evidence of cardioseparate report (38).

In our first patient $(\mathrm{J} . \mathrm{S}$.) we noted lability of ficiency period they had pulse rates of up to 120 pulse rate and a very wide pulse pressure (1). following minor exertion. This was not accom-

\section{ACETYLATION OF PABA}

J.S.

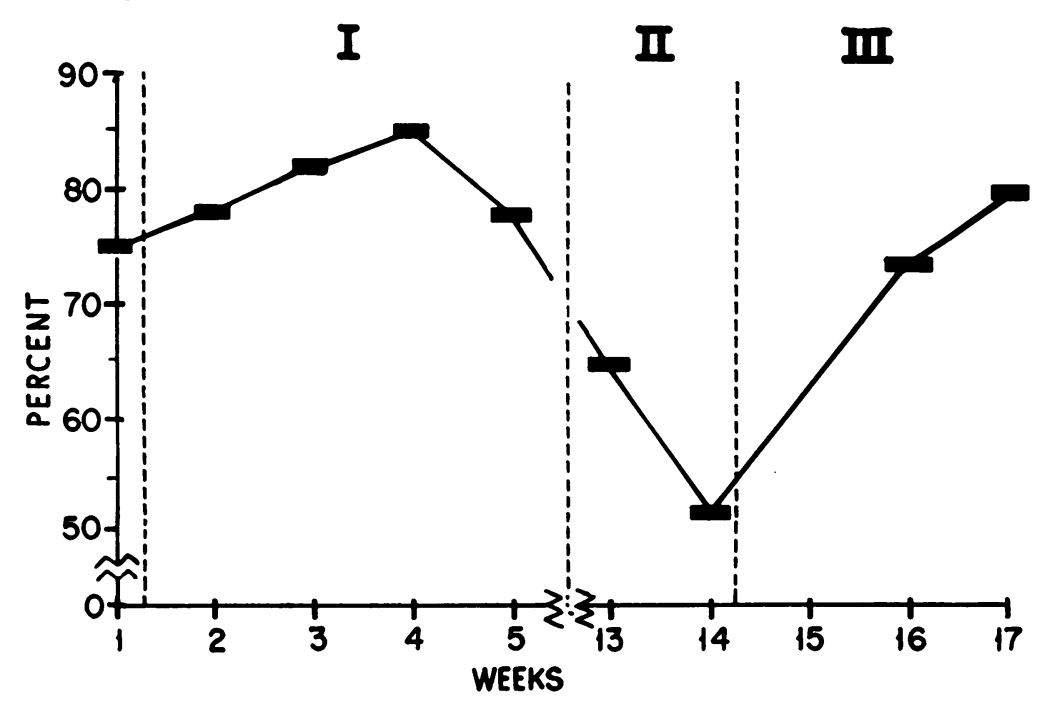

Fig. 4a. Per Cent of Excreted Paba in the Acetylated Form in J. S. 


\section{ACETYLATION Of PABA}

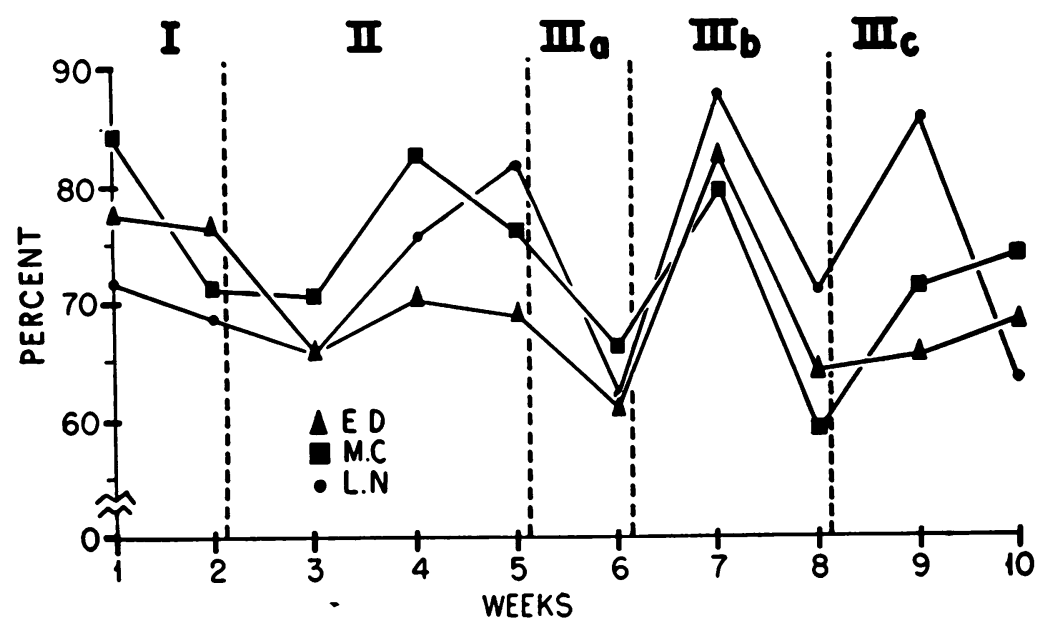

Fig. 4b. Per Cent of Excreted PABA in the Acetylated Form in E. D., M. C., AND L. N.

panied by dyspnea or distress. The basal systolic and diastolic blood pressures decreased. They had some orthostatic instability, occasional dizzy spells, but no fainting. After replacement therapy and cortisone were started, all three subjects had a rise in blood pressure which then gradually returned to normal.

During the deficiency period the three men had almost continual upper respiratory infections, particularly acute pharyngitis. E. D. developed lobar pneumonia at the start of Period II. It responded rapidly to therapy with penicillin. His leukocyte count was 19,800 per cu. mm. with 91 per cent polymorphonuclears. Subsequent studies in two other subjects on the same diet, without the antagonist, given by tube for four weeks, revealed no infection. There was no infection in Period III-c.

The first subject had a steady loss of weight not reversed by replacement of pantothenic acid in the diet. This pattern did not occur in the other subjects. Their weight remained constant until Period III-b, when they suddenly gained about 10 pounds, developed $2+$ ankle edema and a moderate rise in blood pressure. These events antedated cortisone administration in one subject but coincided with it in the other two. Edema disappeared and the weight returned to normal 8

\section{TOLERANCE TESTS}

J.S. I II III

GLUCOSE TOLERANCE
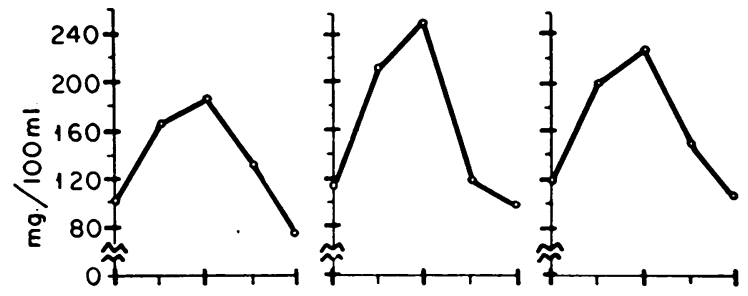

\section{INSULIN TOLERANCE}
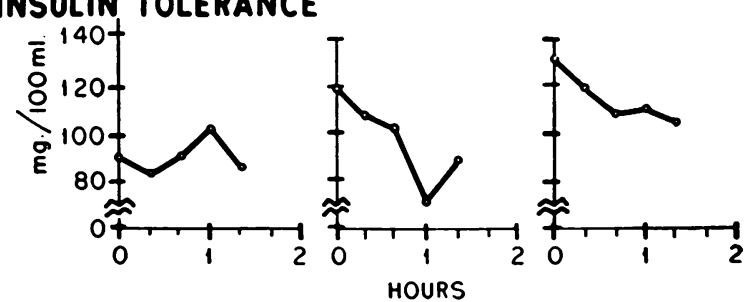

Fig. 5A. Glucose Tolerance and Insulin Sensitivity Curves in J. S.

During the deficiency state the blood glucose rose to high levels, but did not remain elevated very long. At the same time insulin sensitivity increased. In Period II and subsequently 5 instead of 10 units of insulin were used. 


\section{TOLERANCE TESTS}

M.C. I II $\quad$ III $\quad$ III

\section{GLUCOSE TOLERANCE}
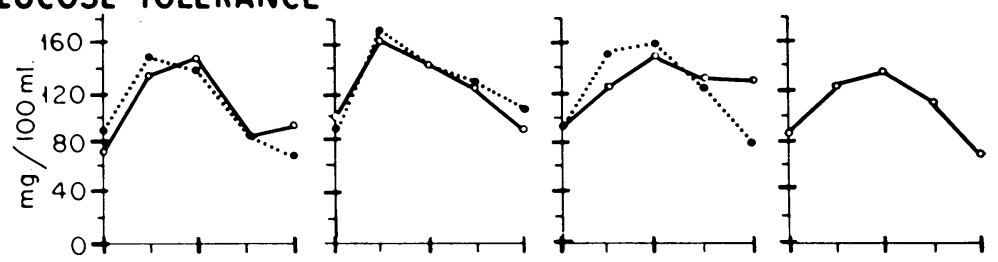

\section{INSULIN TOLERANCE}
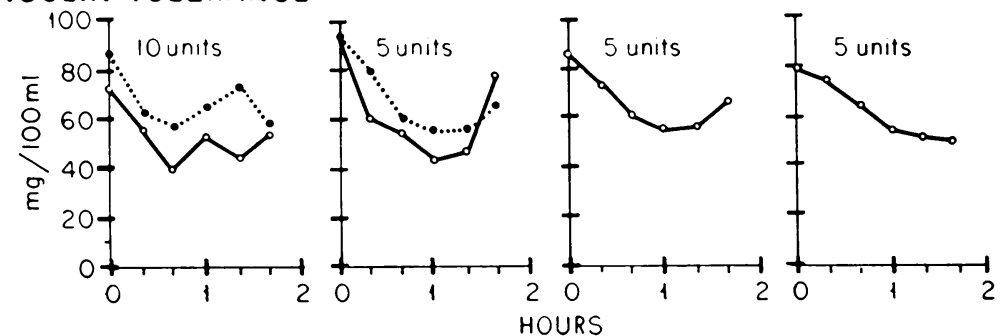

Fig. 5b. Glucose Tolerance and Insulin Sensitivity Tests in Subject M. C.

The dotted lines indicate the second test in a given period.

\section{Plasma proteins \\ (Electrophoresis)}

E.D.

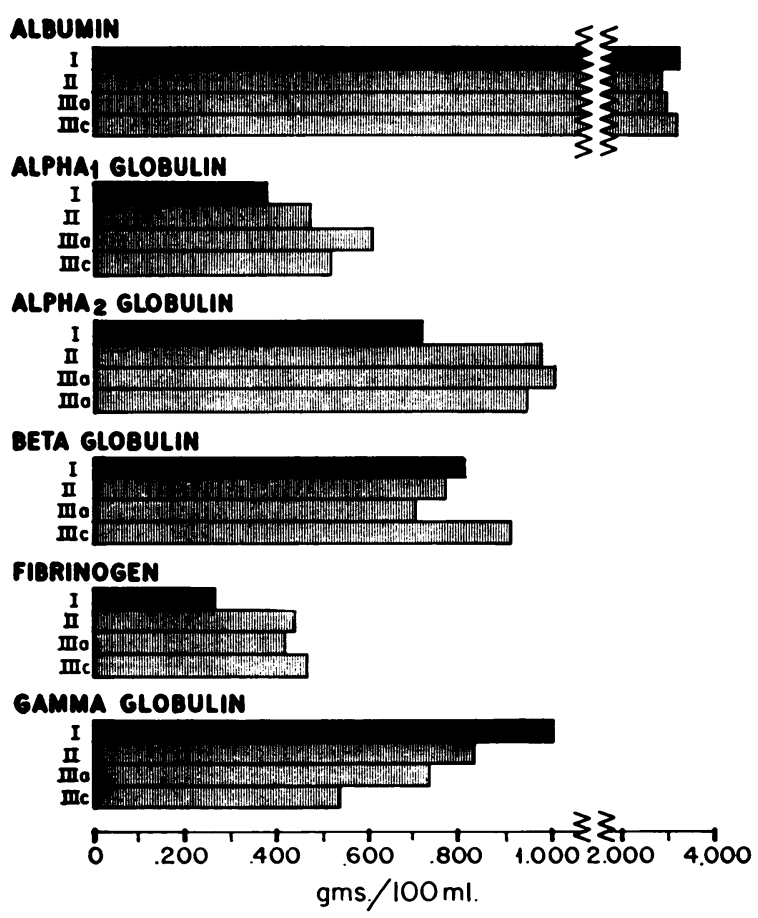

Fig. 6. Plasma Proteins Determined by ElectroPHORESIS to 20 days after the administration of cortisone was stopped.

\section{Metabolic studies}

The subjects normally acetylated 70 to 80 per cent of the excreted PABA. In our first subject (Figure 4A) his percentage fell to about 50 per cent during the deficiency period. In the other three subjects (Figure 4B), however, the per cent of acetylated PABA remained near control levels until Periods III-b and III-c when it fell to 65 per cent. Administration of cortisone was followed by a prompt rise to 82 per cent.

In our first subject glucose tolerance tests showed an elevation in fasting and peak levels of blood sugar (Figure 5A). This pattern was not found in the other subjects (Figure $5 \mathrm{~B}$ ). Insulin tolerance tests, employing 10 units of regular insulin, resulted in troublesome hypoglycemia, so that during Period II, the dose was reduced to 5 units. All four patients had increased insulin sensitivity, which gradually disappeared during the recovery period.

Bromsulphalein tests were normal throughout. Urinary excretion of bile and urobilinogen was likewise normal. The normal serum albumin and 


\section{EOSINOPENIC RESPONSE TO ACTH}

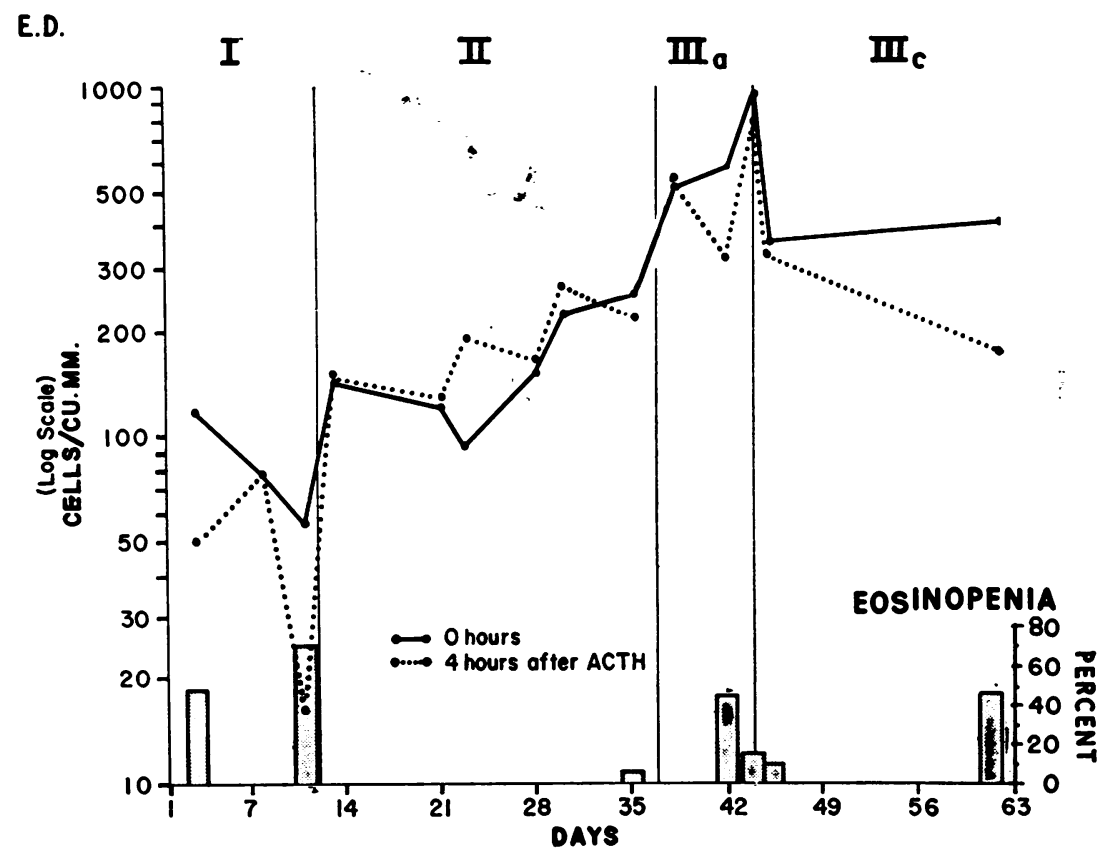

Fig. 7. Eosinophile Response to ACTH

Note the absolute rise of eosinophiles during Period II.

in most instances the normal glucose tolerance curves provided further evidence of normal liver function.

The albumin and total plasma proteins remained constant. However, the alpha ${ }_{1}$ - and alpha ${ }_{2}$ globulins rose in two men and returned toward normal during the close of the observation period (Figure 6). Two of the three men had decreases in the gamma-globulin concentrations. E. D., with a progressive fall in this fraction, had continual severe upper respiratory infections.

During Period I, eosinopenic responses to ACTH usually were normal. In Period II the responses were distinctly impaired or absent (Figure 7). Following addition of pantothenic acid (Period III-a), the eosinopenic responses returned partially and were completely restored in Period III-c. The absolute eosinophile counts rose during the deficiency period and fell during the recovery period.

During Period I, there was great reduction in both cholesterol and esters, but the per cent of esters remained constant (Figure 8). During Period II, the cholesterol levels remained low but late in the period the esters fell as did the per cent of esters. When pantothenic acid was given (Period III-a) the cholesterol esters fell off sharply, but were restored quickly during the administra-

\section{CHOLESTEROL a ESTERS}

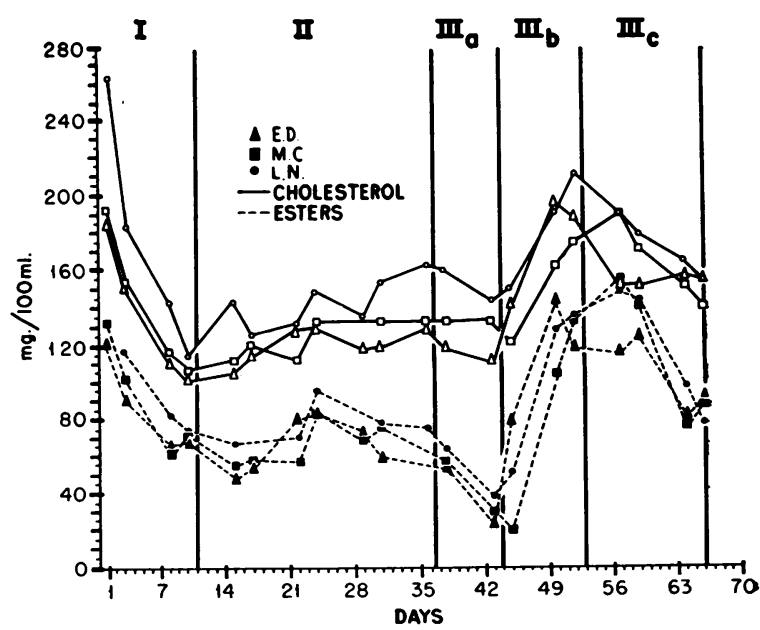

Fig. 8. Cholesterol and Cholesterol Esters 


\section{7-KETOSTEnOIO EXCREtion}

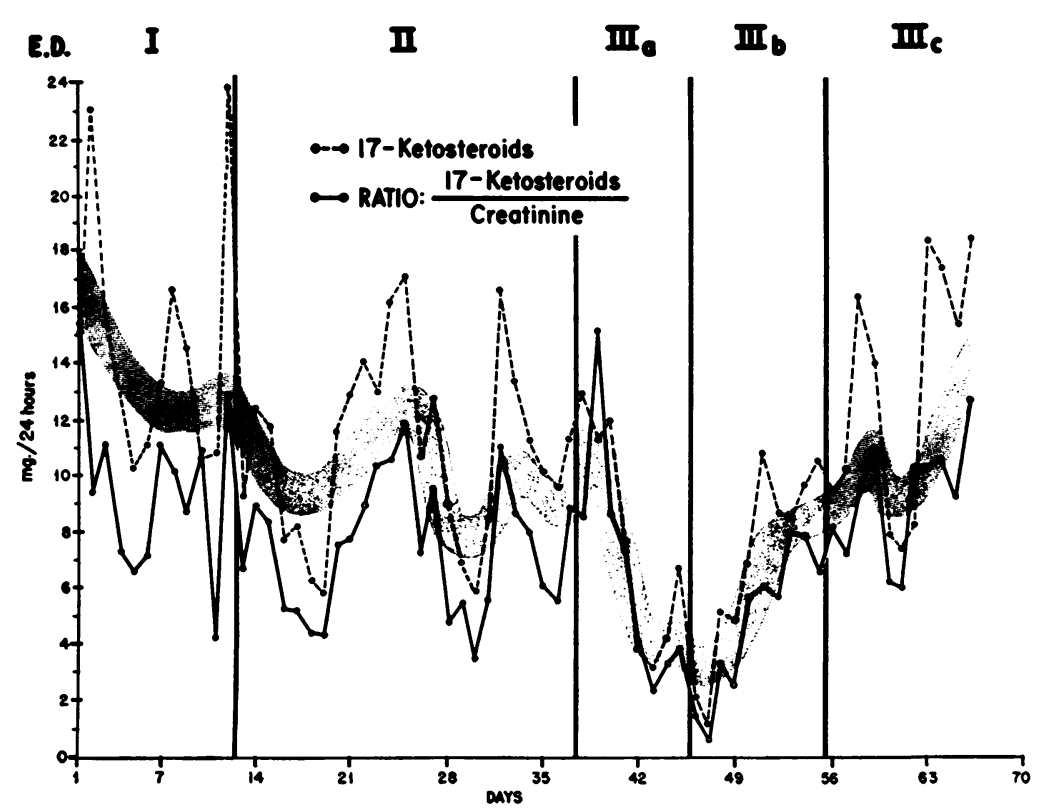

Fig. 9. 17-Ketosteroid Excretion in a Representative Subject

tion of cortisone, vitamins and a nutritious diet (Period III-b).

In subject J. S. there was a gradual decline in urinary 17 -ketosteroid excretion during Period II. Similarly, in two of the three other subjects (Figure 9), the 17-ketosteroid excretion declined during the deficiency period. At the time pantothenic acid was restored to the diet, however, two subjects had a sudden fall in 17-ketosteroid excretion. The 17-ketosteroid excretion gradually rose during the recovery period (III-c).

During Period I the average plasma ascorbic acid levels were 1.6 and $1.5 \mathrm{mg}$. per $100 \mathrm{ml}$. and the average daily excretion in the urine was 40.3 and $74.0 \mathrm{mg}$. in subjects M. C. and L. N. At the end of two weeks of Period II, the plasma levels were zero. The daily urinary excretion had fallen to 19.1 and $38.7 \mathrm{mg}$., respectively.

During the control Period I in one subject 28 per cent of the dietary thiamine was excreted in the urine. This percentage rose to 58 per cent during Period II and fell to 19 per cent during the recovery period. For niacin, 41 per cent was excreted during the control period, 53 per cent during the deficiency period and 35 per cent during the recovery period.
Leukocyte counts were normal throughout. The only change in the differential leukocyte count was a rise in total eosinophiles during Period II. In one man they reached levels between 700 and 900 per cu. mm. During episodes of infection and fever, the expected leukocyte response occurred. The red cell counts and hemoglobin levels fell somewhat. A total of $540 \mathrm{ml}$. of blood was removed during the test (see Table III).

Routine urinalysis failed to demonstrate any abnormalities until the recovery period when L. N. developed a mild proteinuria which accompanied the elevation of blood pressure. Both urine and blood pressure became normal one week later. The somewhat irregular daily urinary output re-

TABLE III

Erythrocyte counts and hemoglobin

\begin{tabular}{llccc}
\hline \hline & & E. D. & L. N. & M. C. \\
\hline Initial & Hgb., Gm./100 ml. & 15.3 & 12.7 & 14.7 \\
& RBC in millions, $\mathrm{mm}$. & 34.56 & 4.32 & 4.39 \\
End of & Hgb. & 13.0 & 11.5 & 13.7 \\
Period II & RBC in millions & 4.18 & 3.98 & 4.54 \\
& & & & \\
End of & Hgb. & 11.2 & 11.0 & 12.6 \\
Period III & RBC in millions & 4.04 & 4.18 & 4.36
\end{tabular}


mained adequate even when edema was developing in all three subjects.

\section{DISCUSSION}

\section{Clinical impressions}

Even without metabolic studies the severe clinical illness, the disturbance of neuromuscular function, and the profound physical and mental depression were clear testimony that the subjects' well-being was altered.

The notorious variability of reactions to, and descriptions of, subjective sensations (39-42) led to underrating the paresthesias. When tendon reflexes became hyperactive and steppage gait and foot drop occurred, the changes were obvious. The unpleasant sensations and later weakness may have come from a disorder of peripheral nerves but the muscles may have been the seat of the trouble.

We did not try to quantitate emotional, intellectual, or psychomotor functions. There was a deterioration in mood, the attitude now sullen and petulant, now quiet and somnolent. How much of the disorder was an emotional reaction to illness and how much was a specific effect of deficiency on the central nervous system is speculative.

The tendency to orthostatic instability varied erratically but did not parallel the complaint of weakness and clumsiness. Sometimes the subjects complained of dizziness, even at rest. There was no nystagmus and the Romberg test revealed unsteadiness no worse than with the eyes open. $\mathrm{X}$-rays of the chest remained normal. The electrocardiogram revealed no change but sinus tachycardia. The abnormalities probably represent more than the neuro-circulatory adjustments to inactivity since they moderated during the recovery period when general activity was still curtailed by weakness.

The upward trend in blood pressure in Period III-b came after cortisone was given. Presumably the sudden effect of the steroid hormone may have been great because the adrenals were relatively inactive. This is in keeping with observations of Lewis and Page (43) on the reduction of induced hypertension in dogs by pantothenic acid deficiency. Nothing suggests an underlying renal disturbance; and the output of urine was very good during this as well as the other stages of the experiment.

The infections which were so troublesome cleared up after a good diet was given. They did not recur during Period III-c or in any subject without the antagonist so it is unlikely that irritation of the pharynx from the tube was a factor.

The relatively small changes in serum protein with an increase in alpha ${ }_{1}$-globulin, alpha ${ }_{2}$-globulin and fibrinogen and a decrease in gamma-globulin are in keeping with the possibility that specific antibodies were not being made adequately. Axelrod (44) and the Zuckers (45) have reported this in animals. There was no granulocytosis such as Weir has described in pantothenic acid deficient mice (46). The rise in eosinophile count was associated with no allergic state. The weight held steady until Period III-b when there was a sudden increase. In two this coincided with the administration of cortisone but in the third subject it began before the day before cortisone was begun.

There was a fall in acetylation during Period I continuing into Period II. Then there was a drift back toward normal and a consistent sharp fall in Period III-a when pantothenic acid was added to the deficient diet and the antagonist. There was a parallel decline in cholesterol esters (Figure 9), but the eosinopenic response to ACTH had come back. In Period III-b acetylation rose only to fall when the next tests were done (Figure 5). This rise may have been induced by cortisone. The fall occurred while clinical improvement was advancing. In the final phase (Period III-c) the trend was back toward normal except for subject L. N.

The sensitivity to insulin increased and we had to reduce the insulin dose from 10 to 5 units, and not give it intravenously. In what degree and indeed whether pantothenic acid deficiency produces this effect directly or through the mediation of the adrenal cortex we do not know. The liver functioned well.

The alterations of plasma protein fractions are similar to those discussed by Wintrobe, Jager, and Thorn (47) as reactions to stress and injury.

Changes in eosinophiles are consistent with the evidence that eosinopenia induced by ACTH depends on the functional integrity of the adrenal cortex, and that this power was lost during the induced deficiency state. Cognate evidence of 
adrenal involvement and its reflection on eosinophiles is the consistent rise in absolute numbers of eosinophiles during the deficiency. They did not return to the baseline figures with the addition of pantothenic acid in Period III-a but came down later. ACTH, $25 \mathrm{mg}$. twice a week, may have disturbed the adrenal cortex.

The diet was devoid of cholesterol and had 90 grams of fat. The steady fall in cholesterol and its esters suggests that the levels of these compounds in the blood was reduced by their absence from the diet, but pantothenic acid metabolism may have been involved. During Period III-a when pantothenic acid was added cholesterol stayed the same but the esters dropped at the same time the 17 -ketosteroid excretion was falling, eosinopenia induced by ACTH had returned, and acetylation was depressed. In Period III-c another roughly parallel decline in cholesterol and esters was not so fast nor so great as the initial fall. This difference may have been caused by the higher level of pantothenic supplementation, or by the residual effects of the cortisone and good diet.

The tendency for a diminished 17-ketosteroid excretion during Period II was exaggerated during Period III-a when pantothenic acid was given. This alteration occurred in phase with the fall in cholesterol esters, the decline in acetylation and the return of the eosinopenic response to ACTH. Excretion of 17-ketosteroids remained low until cortisone therapy was discontinued. It then rose steadily but slowly until the end of the experiment. We interpret these observations as indicating a disorder in adrenal cortical function induced by the deficiency in pantothenic acid.

Unpublished observations on two subjects were made by J. F. Manresa (48). In both subjects plasma ascorbic acid had become zero by the end of the second week of the deficiency period (ii), and the 24-hour excretion was reduced by half. No clinical signs of scurvy appeared. Beyond the well known connection of ascorbic acid and adrenal function (16) we have no idea what this observation signifies.

G. A. Amago (49) studied the excretion of thiamine and niacin in the urine of one subject. Excretion of thiamine rose significantly and excretion of niacin rose somewhat during pantothenic deficiency and returned to the control levels after the depletion period. One of the master puzzles in clinical nutrition concerns the interrelationships of the many individual vitamins of the $\mathrm{B}$ complex. Our observations are not adequate for general conclusions. It is unlikely that the increased vitamin excretion could have caused any of the observed clinical disorders. This needs to be tested by further investigation.

We tried to measure that adrenal cortical function determined by challenging the subject with a large drink of water (30). The data are unsatisfactory because by the end of the first week of the small feedings of Period I, drinking the large quantity of water caused prompt diarrhea by a gastrocolic reflex. As this was never wholly overcome the inadequate response to the water may have represented reduced absorption. The response was essentially normal in Period III-b. It was our impression that adrenal hypofunction was responsible for part of the low excretion.

\section{Comments}

We would emphasize particularly the small number of subjects and the considerable variations among them. The experiments were acute and severe. A milder deficiency lasting much longer might have produced a different state of disease. In the nature of our experimental plan we had to accept certain artifacts. Blood taken for tests probably contributed to the slight anemia. ACTH used to test eosinophile response no doubt had other effects on the adrenal cortex. The small volume of the formula and its low residue altered the bowel habits. Ingestion of a large amount of water was followed shortly by a watery diarrhea, thus obscuring any deterioration in the adrenal function of facilitating diuresis.

The production of physical illness, a neuromotor disorder and a series of biochemical disturbances by a diet devoid of pantothenic acid with an antagonist suggests that pantothenic acid is essential for man. We suggest further that the "burning feet" element of naturally occurring deficiency states may be mediated by pantothenic acid deficiency. This is in keeping with the clinical experiences reported by Gopalan (50). We are now testing a method of inhibiting some functions of the adrenal cortex by a reversible metabolic approach for a possible therapeutic role in ad- 
vanced hypertension and diabetes and in various kinds of neoplastic disease. We are studying the possible connections of pantothenic acid metabolism with the dissecting aneurysm-kyphoscoliosis syndrome induced in rats by $\beta$-amino-propionitrile (Figure 1) $(51,52)$. This syndrome has some analogy with clinical lathyrism (42) and has some features in common with induced pantothenic deficiency. A diet with excessive quantities of sweet pea meal (Lathyrus odoratus) was the clue to finding the toxic factor producing the dissecting aneurysm-kyphoscoliosis syndrome in growing rats.

\section{CONCLUSIONS}

1. Subjects on a diet devoid of pantothenic acid, and with an antagonist, omega-methylpantothenic acid developed: 1) a neuromotor disorder; 2) cardiovascular instability especially in the upright position; 3) complaints referable to the alimentary canal; 4) repeated infections; and 5) physical and mental depression. They were not all relieved promptly by adding pantothenic acid to the diet.

2. The biochemical changes included alterations in acetylation, carbohydrate metabolism, blood cholesterol, steroid hormone excretion, plasma protein; and failure of ACTH to induce eosinopenia.

3. The individual variations were large.

\section{ACKNOWLEDGMENTS}

To the subjects John Suchomel, Marvin Cowman, Earl Dolquist, and Laverne Nelson we wish to express gratitude. Without the help of the nurses and their assistants, this experiment could never have left the planning stage. We are especially indebted to Gladys Rittenmeyer, Helen Huebner, Ula Clark, and Emily Stoughton.

\section{REFERENCES}

1. Bean, W. B., and Hodges, R. E., Pantothenic acid deficiency induced in human subjects. Proc. Soc. Exper. Biol. \& Med., 1954, 86, 693.

2. Woods, D. D., The relation of $p$-aminobenzoic acid to the mechanism of the action of sulphanilamide. Brit. J. Exper. Path., 1940, 21, 74.

3. Woolley, D. W., Strong, F. M., Madden, R. J., and Elvehjem, C. A., Anti-black tongue activity of various pyridine derivatives. J. Biol. Chem., 1938, 124, 715.
4. Bean, W. B., Spies, T. D., and Blankenhorn, M. A., Secondary pellagra. Medicine, 1944, 23, 1 (p. 58) ).

5. Williams, R. J., Lyman, C. M., Goodyear, G. H., Truesdail, J. H., and Holaday, D., "Pantothenic acid," a growth determinant of universal biological occurrence. J. Am. Chem. Soc., 1933, 55, 2912.

6. Lipmann, F., Acetylation of sulfanilamide by liver homogenates and extracts. J. Biol. Chem., 1945, $160,173$.

7. Novelli, G. D., Metabolic functions of pantothenic acid. Physiol. Rev., 1953, 33, 525.

8. Guehring, R. R., Hurley, L. S., and Morgan, A. F., Cholesterol metabolism in pantothenic acid deficiency. J. Biol. Chem., 1952, 197, 485.

9. Winters, R. W., Schultz, R. B., and Krehl, W. A., The adrenal cortex of the pantothenic acid-deficient rat: Eosinophile and lymphocyte responses. Endocrinology, 1952, 50, 377.

10. Ralli, E. P., Pantothenic acid in The Vitamins, Vol. II, W. H. Sebrell, Jr., and R. S. Harris, eds., New York, The Academic Press, 1954, vol. II, p. 669, p. 687.

11. Stanbery, S. R., Snell, E. E., and Spies, T. D., A note on an assay method for pantothenic acid in human blood. J. Biol. Chem., 1940, 135, 353.

12. Drell, W., and Dunn, M. S., Growth inhibition of lactic acid bacteria by $\mathrm{N}$ - $(\alpha, \gamma$-dihydroxy- $\beta, \beta$-dimethylvaleryl) $-\beta$-alanine and its reversal by pantothenic acid. J. Am. Chem. Soc., 1946, 68, 1868.

13. Drell, W., and Dunn, M. S., Inhibition of lactic acid bacteria by analogs of pantothenic acid. J. Am. Chem. Soc., 1948, 70, 2057.

14. Schinazi, L. A., Drell, W., Ball, G. H., and Dunn, M. S., Toxicity and effect of $\omega$-methylpantothenic acid on blood-induced infections of Plasmodium lophurae in the chick. Proc. Soc. Exper. Biol. \& Med., 1950, 75, 229.

15. Drell, W., and Dunn, M. S., Production of pantothenic acid deficiency syndrome in mice with $\omega$-methylpantothenic acid. Arch. Biochem. \& Biophys., 1951, 33, 110.

16. Shils, M. E., Pantothenic acid deficiency and conjugation reactions. III. Inhibitory effect of $\omega$-methylpantothenic acid. Proc. Soc. Exper. Biol. \& Med., 1950, 75, 352.

17. Bean, W. B., A testament of duty: Some strictures on moral responsibilities in clinical research. J. Lab. \& Clin. Med., 1952, 39, 3.

18. Barnett, J. W., and Robinson, F. A., Analogues of pantothenic acid: 2. Preparation of growth inhibitors. Biochem. J., 1942, 36, 364.

19. Bratton, A. C., and Marshall, E. K., Jr., A new coupling component for sulfanilamide determination. J. Biol. Chem., 1939, 128, 537.

20. Robbie, W. A., and Gibson, R. B., Rapid clinical determination of urinary 17 -ketosteroids. J. Clin. Endocrinol., 1943, 3, 200.

21. Schoenheimer, R., and Sperry, W. M., A micromethod for the determination of free and combined cholesterol. J. Biol. Chem., 1934, 106, 745. 
22. Hills, A. G., Forsham, P. H., and Finch, C. A., Changes in circulating leukocytes induced by the administration of pituitary adrenocorticotrophic hormone (ACTH) in man. Blood, 1948, 3, 755.

23. Randolph, T. G., Differentiation and enumeration of eosinophils in the counting chamber with a glycol stain; a valuable technique in appraising ACTH dosage. J. Lab. \& Clin. Med., 1949, 34, 1696.

24. Gompertz, L. M., and Cohen, W., The effect of smaller doses of histamin in stimulating human gastric secretion. Am. J. Med. Sc., 1929, 177, 59.

25. Babkin, B. P., The triple mechanism of the chemical phase of gastric secretion. Am. J. Digest. Dis., 1938, 5, 467.

26. Lövi, L., Zucker-Probefrühstücke. Wien. klin. Wchnschr., 1932, 45, 460.

27. Cheney, G., A simplified method of gastric analysis. Am. J. Med. Sc., 1929, 177, 110.

28. Myers, G. B., and McKean, R. M., The oral glucose tolerance test. Am. J. Clin. Path., 1935, 5, 299.

29. Folin, O., A new blood sugar method. J. Biol. Chem., 1928, 77, 421.

30. Robinson, F. J., Power, M. H., and Kepler, E. J., Two new procedures to assist in the recognition and exclusion of Addison's disease: A preliminary report. Proc. Staff Meet., Mayo Clinic, 1941, 16, 577.

31. Weichselbaum, T. E., An accurate and rapid method for the determination of protein in small amounts of blood serum and plasma. Am. J. Clin. Path. (Technical Section), 1946, 10, 40.

32. Longsworth, L. G., Shedlowsky, T., and MacInnes, D. A., Electrophoretic patterns of normal and pathological human serum and plasma. J. Exper. Med., 1939, 70, 399.

33. Huff, J. W., and Perlzweig, W. A., The fluorescent condensation product of $\mathrm{N}^{\prime}$-methylnicotinamide and acetone. II. A sensitive method for the determination of $\mathrm{N}^{\prime}$-methylnicotinamide in urine. $\mathrm{J}$. Biol. Chem., 1947, 167, 157.

34. Najjar, V. A., and Wood, R. W., Presence of a hitherto unrecognized nicotinic acid derivative in human urine. Proc. Soc. Exper. Biol. \& Med., 1940, 44, 386.

35. Hennessy, D. J., and Cerecedo, L. R., The determination of free and phosphorylated thiamin by a modified thiochrome assay. J. Am. Chem. Soc., 1939, 61, 179.

36. Stotz, E., A clinical method for the determination of ascorbic acid in blood plasma and urine. J. Lab. \& Clin. Med., 1941, 26, 1542.
37. Bean, W. B., Control in research in human nutrition. Nutrition Rev., 1950, 8, 97.

38. Thornton, G. H. M., Bean, W. B., and Hodges, R. E., The effect of pantothenic acid deficiency on gastric secretion and motility. J. Clin. Invest., 1955, 34, 1085.

39. Bean, W. B., Franklin, M., and Sahs, A. L., An effect of vitamin $B_{12}$ on pain in nutritional neuropathy. Am. J. Med. Sc., 1950, 220, 431.

40. Walshe, F. M. R., Aetiology of polyneuritis. Lancet, 1941, 1, 33.

41. Spillane, J. D., Nutritional Disorders of the Nervous System. Baltimore, Williams and Wilkins Co., 1947.

42. Denny-Brown, D., Neurological conditions resulting from prolonged and severe dietary restriction, (Case reports in prisoners-of-war, and general review). Medicine, 1947, 26, 41.

43. Lewis, L. A., and Page, I. H., Pantothenic acid deficiency in experimental renal hypertension in dogs. Am. J. Physiol., 1953, 173, 359.

44. Axelrod, A. E., Role of the vitamins in antibody production (A summation of the author's work to date). Metabolism, 1953, 2, 1.

45. Zucker, T. F., and Zucker, L. M., Pantothenic acid deficiency and loss of natural resistance to a bacterial infection in the rat. Proc. Soc. Exper. Biol. \& Med., 1954, 85, 517.

46. Weir, D. R., Leukocyte production in pantothenic acid-deficient mice. J. Nutrition, 1953, 49, 425.

47. Wintrobe, M. M., Jager, B. V., and Thorn, G. W., Reactions to injury in Principles of Internal Medicine, 2nd ed., T. R. Harrison, ed., New York, Blakiston Co., 1954, p. 488.

48. Manresa, J. F., Blood ascorbic acid levels and urinary excretion in various stress situations, Thesis for M.S. in Nutrition, State University of Iowa, 1954.

49. Amago, G. A., The urinary excretion of thiamine and niacin on a pantothenic acid deficient regimen, Thesis for M.S. in Nutrition, State University of Iowa, 1954.

50. Gopalan, C., The 'burning-feet' syndrome. Indian M. Gaz., 1946, 81, 22.

51. Ponseti, I. V., and Baird, W. A., Scoliosis and dissecting aneurysm of the aorta in rats fed with Lathyrus odoratus seeds. Am. J. Path., 1952, 28, 1059.

52. Bean, W. B., and Ponseti, I. V., Dissecting aneurysm produced by diet. Circulation, In press. 